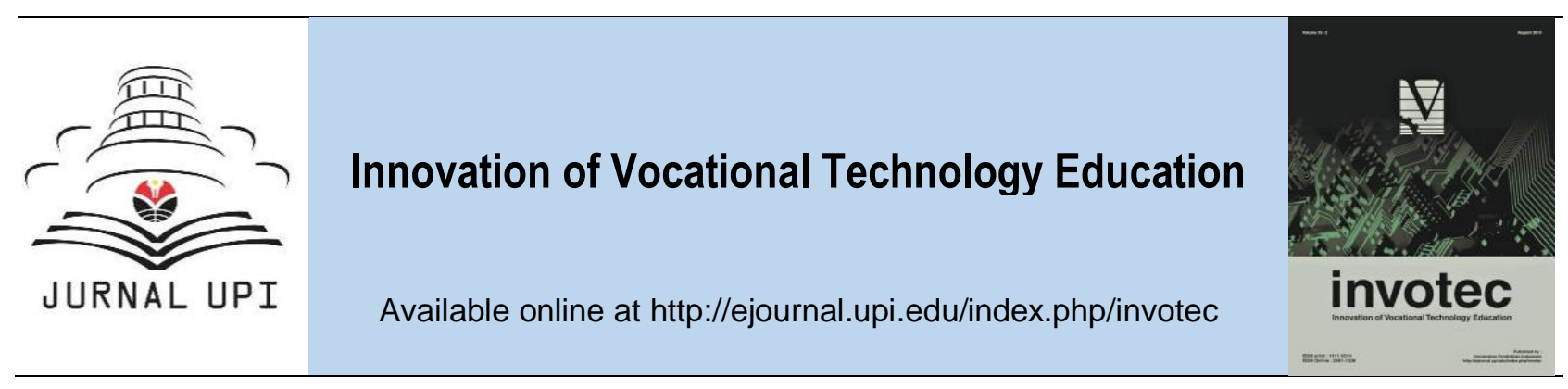

\title{
The Analysis of Learning Implementation Plan in Vocational Subjects Based on 2013 Curriculum
}

\author{
M. A. Hamid, M. Nurtanto, M. Fawaid \\ Universitas Sultan Ageng Tirtayasa, Indonesia
}

\section{ARTICLE INFO}

Article history:

Received 23 October 2017

Received in revised form 22 November 2017

Accepted 30 November 2017

Available online 28 February 2017

Keywords:

Curriculum 2013,

Learning Implementation

Plan,

Vocational education

Corresponding author:

abi.mustofa@untirta.ac.id
A B S T R A C T

The qualified teacher is teacher who has the standards of educator that has capability of their materials according to the standard of the contents and carry out the learning process according to the standard of the process. Learning Implementation Plan (LIP) is the administration prepared teachers before carrying out the learning process. This research aims to know the quality of the LIP who made by teachers. This research is a descriptive qualitative. The data were collected through questionnaire, document's noting, and interviews method. The research subjects are vocational teachers in SMK Negeri 1 Cilegon. The results of this research shows that (1) the completeness of the components 63.63; (2) conformity between components 85.7; (3) feasibility of competence 100 ; (4) feasibility of the indicators and the achievement of basic competencies 100 ; (5) feasibility of the learning objectives 80 ; (6) formulate learning objectives 75 ; (7) choosing and organizing the learning material 80 ; (8) feasibility of the learning activities 84.6 ; (9) selection of learning methods 100 ; (10) selection of media, tools and learning resources 85.71; and (11) the feasibility assessment 85.7 , so that the average was 85.5 with good qualifications. The LIP is structured properly can increase the effectiveness of learning in the classroom and improve the quality of teaching and graduates are in accordance with the needs of the ASEAN Economic Community.

\section{Introduction}

Vocational education plays an important role to educate and train the younger generation to face globalization, technological change, economic challenge, social and cultural changes affecting community life. Vocational education in Indonesia has the responsiability to educate and train them to be productive workforces, which must be able to compete in the international market. Quality learning process is inseparable from the role of teacher quality in the transfer of knowledge and the transfer of value to students. Teachers must have the academic qualification and competence as an agent of healthy learning, physical and spiritual, as well as being able to realize the goals of education. The competence that should be possessed by the teachers in order to meet the standards of professional competence is the educator (science), pedagogic competency, personality competency, and social competency. This is according to (Miarso, 2008) said that 
qualified teacher is a teacher who full fill of the educator standards, master of their material/content according to standard content, not only live up but also carry out the learning process according to standards process of learning. The teacher acts as a facilitator and guiding students in their learning process. The teachers no longer puts himself acted as the only model for learning and the only one who is able to find and correct student mistakes (Purwo, 2009). So, teacher and student are active together to create a learning atmosphere that interesting and effective to improve student learning outcomes. Learning interesting and effective can increase the student competence that competitive to confront in AEC (ASEAN Economic Community).

Teacher is a person who has ability to design the learning programs as well as being able to organize and manage the classroom so that students can learn and eventually they can reach a level of maturity as the ultimate goal of the educational process (Uno, 2007). The ability to design the learning program is an ability to design and make a good LIP based on standards. So that the learning will be implemented in accordance with the planning will able to increase the student competence, so that the students can compete in the era of MEA. The LIP has been designed then applied in the learning process in class and balanced with capabilities to organizing and managing class.

Effective teachers know that one of their primary tasks is to involve the student in the learning process (Cooper \& Tenbrink, 2011). Student need to engage directly and active during the learning process. Teacher as a facilitator in learning has to give motivation, encouragement, guidance and reinforcement materials to the students so that learning atmosphere is created that is effective and efficient. An effective learning process can be created if it had been well planned. Preparation of learning is like prepare the soil for planting seeds. If done correctly, would create a good condition for healthy growth (Ruhimat, et. al. 2011). Thus, the preparation of learning process is done by preparing a good and effective LIP, so learning which is good and effective will be created.

\section{Method}

This research was using a descriptive quantitative approach. This research was carried out in SMKN 1 Cilegon and the research subject is a vocational teacher as many as 23 people. The reason why SMKN 1 Cilegon as a research location because is a pilot project of 2013 Curriculum implementation. So in the practice, it is get monitoring directly from a team of curriculum and trustees primarily in the manufacture of learning device, it is LIP through several stages of evaluation. Time of implementation began in May until June 2016. The method of data collection is using form, written records and the structured interviews was validated by expert jugdements. Assessment results LIP converted based on the following criteria: $81.25 \%<$ skor $\leq 100 \%$ is very good; $62.50 \%<$ skor $\leq 81.24 \%$ is good; $43.75 \%<$ skor $\leq 62.49 \%$ is bad; and $25.00 \%<$ skor $\leq 43.74 \%$ is very bad. LIP is decent and valid on good and very good criteria.

\section{Result and Discussion}

Data retrieval fees learning administration is done by doing observation directly related LIP every teacher vocational subjects in accordance with their subject. The next LIP is observed according to checklist mark that has been provided. From the next checklist data is made an average based on aspect or variable that is adapted to the systematics of LIP (Table 1).

The results of the acquisition LIP aspects shows 3 (three) on the good category either and 8 (eight) in the very good category. It can be concluded that implementation of LIP preparation of vocational teachers in SMKN 1 Cilegon have full fill the criteria that was set out. In order to strengthen quantitative data, then conducted an interviews of each vocational teacher related the important of preparation the LIP and the obstacles encountered in its compilation. The important reason of LIP for vocational teachers in general are: (1) the teacher should make the LIP due to load the goal of learning in which each subject will have different goals, (2) without LIP then the learning process in class will be difficult to control, (3) a minimum of making a LIP, teachers will know the material to be taught to their students. The obstacle reason in the making of LIP are: (1) designing the LIP to be able to identify the student center, (2) Pack the LIP which could develop and stimulate the student in the learning process, (3) determine the core competency and the basic 
competency and relating the syllabus to the LIP, (4) specifies the verb in the basic competency and achievement indicators according to the grade of class.

Table 1. The Aspect of LIP Assessment in 2013 Curriculum

\begin{tabular}{llcc}
\hline No & The Aspect of LIP Assessment in 2013 Curriculum & Score & Criteria \\
\hline 1 & The completeness of LIP component & $63.6 \%$ & Good \\
2 & Conformity Between Components & $85.7 \%$ & Very Good \\
3 & The Feasibility of Core Competence & $100.0 \%$ & Very Good \\
4 & The feasibility of the Basic Competencies and indicators of & $100.0 \%$ & Very Good \\
& competence achievement & $80.0 \%$ & Good \\
5 & The Feasibility of Learning goals & $75.0 \%$ & Good \\
6 & The Formulation of Learning goals & $80.0 \%$ & Good \\
7 & The selesting and organizing of Learning Materials & $84.6 \%$ & Very Good \\
8 & The Feasibility of the Learning Activities & $100.0 \%$ & Very Good \\
9 & The Selection of Learning Methods & $85.7 \%$ & Very Good \\
10 & The selection of Media, tools and learning resources & $85.7 \%$ & Very Good \\
\hline
\end{tabular}

The Completeness of LIP component is a systematics of the LIP, which is to making a LIP have to contains learning goals, how the delivery and the way its assessment. In this research, the completeness of LIP consists of 11 aspects/indicators contains: $\left(a_{1}\right)$ the identity of the subjects; $\left(\mathrm{a}_{2}\right)$ the core competenciy consist of $\mathrm{KI} 1, \mathrm{KI} 2, \mathrm{KI} 3$, and $\mathrm{KI} 4 ;\left(\mathrm{a}_{3}\right)$ the basic competency and indicators of achievement; $\left(a_{4}\right)$ learning goals; $\left(a_{5}\right)$ learning material; $\left(a_{6}\right)$ the method of learning; $\left(a_{7}\right)$ learning resources; $\left(a_{8}\right)$ tools and learning media; $\left(a_{9}\right)$ steps of the learning activities; $\left(a_{10}\right)$ assessment; $\left(\mathrm{a}_{11}\right)$ verification of the principal or vice principal. Based on the 11 aspects above, the average result is $63.6 \%$.

The systematics of LIP has been made should have continuity between components, intended to have integration and not deviate from what has been planned. In conformity assessment between components that become a benchmark is: (b1) the conformity of core components, basic components, and indicators achievement of competence; (b2) the suitability of indicator achievement of competence with the goals of learning; (b3) the conformity of learning methods with the purpose of learning, learning activities and indicators; (b4) the suitability between the media, tools and learning resources with learning goals, indicators, and learning activities; (b5) the conformity between the indicator of achievement with learning assessments; (b6) the conformity between core activities with the syllabus, learning material and indicators; and (b7) the conformity between assessments with learning goals, indicators, and learning material. Based on 7 (seven) aspects above, the conformity between components obtained an average which is $85.7 \%$.

The Completeness of LIP component is a systematics of the LIP, which is to making a LIP have to contains learning goals, how the delivery and the way its assessment. In this research, the completeness of LIP consists of 11 aspects/indicators contains: $\left(a_{1}\right)$ the identity of the subjects; $\left(\mathrm{a}_{2}\right)$ the core competenciy consist of $\mathrm{KI} 1, \mathrm{KI} 2, \mathrm{KI}$, and $\mathrm{KI} 4 ;\left(\mathrm{a}_{3}\right)$ the basic competency and indicators of achievement; $\left(a_{4}\right)$ learning goals; $\left(a_{5}\right)$ learning material; $\left(a_{6}\right)$ the method of learning; $\left(a_{7}\right)$ learning resources; $\left(a_{8}\right)$ tools and learning media; $\left(a_{9}\right)$ steps of the learning activities; $\left(a_{10}\right)$ assessment; $\left(a_{11}\right)$ verification of the principal or vice principal. Based on the 11 aspects above, the average result is $63.63 \%$.

The systematics of LIP has been made should have continuity between components, intended to have integration and not deviate from what has been planned. In conformity assessment between components that become a benchmark is: (b1) the conformity of core components, basic components, and indicators achievement of competence; (b2) the suitability of indicator achievement of competence with the goals of learning; (b3) the conformity of learning methods with the purpose of learning, learning activities and indicators; (b4) the suitability between the media, tools and learning resources with learning goals, indicators, and learning activities; (b5) the conformity between the indicator of achievement with learning assessments; (b6) the conformity between core activities with the syllabus, learning material and indicators; and (b7) the conformity between assessments with learning goals, indicators, and learning material. Based on 7 (seven) aspects above, the conformity between components obtained an average which is $85.7 \%$.

Core competencies was developed from Permendikbud which contains aspects of spiritual attitude, social attitude, cognitive and psychomotor of many levels. The feasibility of core 
competence consists of two aspects, namely: (C1) formulation of core competencies; and (C2) the development of core competence based on aspects of the assessment. Obtained an average of eligibility core competence that is equal to $100 \%$.

Basic competence is a reduction of core competence and contains of psychomotor and cognitive competencies and contains of product competence. The indicator is specifically basic competencies that can be used as a measure to know the results of the learning achievement (Majid, 2008). The feasibility of core competence and indicators of achievement contains of several aspects: $\left(d_{1}\right)$ basic competencies include of attitudes, knowledge, and skills; $\left(d_{2}\right)$ the elaboration of indicator of knowledge achievement and skills based on $\mathrm{KI} 3$ and $\mathrm{KI} 4$; $\left(\mathrm{d}_{3}\right)$ indicators compiled using the verb operational; $\left(d_{4}\right)$ knowledge describes the dimensions of cognitive processes; $\left(d_{5}\right)$ the skill contains of psychomotor levels. Obtained an average of $100 \%$.

Learning goals is the core of learning achievement. Students take when what they were learning was relevant to everyday life. Aspects of the learning goals required in accordance with: $\left(e_{1}\right)$ learning material; $\left(e_{2}\right)$ learning methods; $\left(e_{3}\right)$ learning activities; $\left(e_{4}\right)$ learning resources; and $\left(e_{5}\right)$ an assessment of the results study. The result of the feasibility of the learning goals is $80.0 \%$.

In addition to the feasibility in making learning objectives need to be formulated with the intention of results achievement and does not have another meaning. The aspect of the formulation of learning goals are: $\left(f_{1}\right)$ does not give rise to a double interpretation; $\left(f_{2}\right)$ containing the operational of verbs and containing the substance of the material; $\left(f_{3}\right)$ based on basic competence; $\left(\mathrm{f}_{4}\right)$ illustrates the process of achieving the intended purposes. The result of the formulation of the learning goals is $75.0 \%$.

Learning materials is a core subject that is delivered to students, so it will be needed clarity in source that can be justified. In addition the material is too broad, in order to become focus of the purpose it is necessary to organize or selection of appropriate. The teaching materials are the subjects of learning materials that students need to learn as a means of achieving basic capabilities will be assessed using the instrument of assessment which is based on learning achievement indicators (Susilo, 2007). Selecting and organizing of learning materials in the LIP consists of: $\left(g_{1}\right)$ selected based on goals or competencies will be achieved; $\left(g_{2}\right)$ structuring the material customized learning characteristic; $\left(g_{3}\right)$ possible flexibility and depth of the material can be achieved in accordance with the desired time; $\left(g_{4}\right)$ has more than one source; and $\left(g_{5}\right)$ learning material contains factual knowledge, conceptual, procedural, and metacognition. The results of the selecting and organizing the learning material obtained an average of $80.0 \%$.

The process of learning implementation is contained in the learning activities, which describes the activities of the teachers during learning activity. Learning activities includes a series of activities to be undertaken by student in sequence to achieve basic competence (Efendi, 2009). Learning activity itself is divided into three (3) main activities consisting of introduction, core and cover. The aspect of the learning activities are judged include: (a) preliminary activities consist of: $\left(h_{1}\right)$ appreciation; $\left(h_{2}\right)$ the learning motivation; $\left(h_{3}\right)$ learning goals, $(b)$ the core activities included: $\left(h_{4}\right)$ observing activities; $\left(h_{5}\right)$ asking activity; $\left(h_{6}\right)$ information gathering activities; $\left(h_{7}\right)$ reasoning activities; $\left(h_{8}\right)$ communicating activities; $\left(h_{9}\right)$ the activity that describe the learning process which interactive, inspiring, fun, challenging and motivating students, and (c) the concluding activities included: $\left(h_{10}\right)$ learning; $\left(h_{11}\right)$ the assessment or reflection against the learning that has been implemented; $\left(h_{12}\right)$ feedback on the process and results of the study; $\left(h_{13}\right)$ planned the follow-up activities such as remedial, enrichment or the provision of duty; $\left(\mathrm{h}_{14}\right)$ the learning information that will be dating; and (3) submission of the achievement of the KD (basic competence) from KI (core competence) 1 (spiritual) and $\mathrm{KI} 2$ (social). The acquisition results of the feasibility aspects of the learning activities obtained an average of $84.6 \%$.

The method used in the learning process is expected that students active and can form strategies in planning learning in class. The function of learning method or learning model according to (Zubaidah, 2010) is the guidelines of design and learning implementation. The selection of the learning methods consists of two aspects, namely: $\left(i_{1}\right)$ relevant to the scientific approach; and $\left(\mathrm{i}_{2}\right)$ contain of scientific stages. The result of the selection of learning method is $100.0 \%$.

Learning requires a supporting infrastructure, known as the media, tools or learning resources. Supporting facilities and infrastructure more complex, it will be easier for students to understand and accept the learning. Media can represent what is less able to recite teacher through words or sentences (Djamarah and Zain, 2006). Even abstractness materials can be 
concretized by the presence of media. So learning resources disclosed by (Hasan, 2013), the strengthening of governance Curriculum 2013 consists of: (1) preparing the Handbook of learning for students and teachers, (2) preparing teachers in order to understand the utilization of learning resources that have been prepared and other sources that they can take advantage of, and (3) strengthening the role of mentoring and monitoring by the central and local implementation of learning. From the aspect above consist of several indicators include: $\left(j_{1}\right)$ in accordance with the characteristics of the students; $\left(j_{2}\right)$ in accordance with the scientific learning; $\left(j_{3}\right)$ learning resources in accordance with the competencies achieved; $\left(\mathrm{j}_{4}\right)$ the selected learning resource facilitate understanding; $\left(\mathrm{j}_{5}\right)$ learning resource described according to specific; $\left(\mathrm{j}_{6}\right)$ contain the content of the cognitive, psychomotor, and affective; $\left(j_{7}\right)$ the writing of learning resources in accordance with the EYD. As for the results of the selection media, tools and learning resources of $85.7 \%$.

The most important component of the learning process is the assessment of each basic competence or indicator of achievement learning. Indicator of learning outcomes assessment consists of: (a) instruments of daily test; (b) availability a key answer; (c) the full and appropriate assessment instruments; (d) guidelines of spiritual aspects assessment; (e) guidelines of social aspects assessment; ( $f$ ) guidelines of cognitive aspects assessment; and (g) guidelines of psychomotor aspects assessment. The results from the aspect of learning outcomes assessment is $85.7 \%$.

\section{Conclusion}

The vocational teachers at SMKN 1 Cilegon in preparation of LIP overall has a very good criteria. SMK N 1 Cilegon as a pilot project in the preparation of LIP have reached the criteria very well. This is proven by the LIP component aspects in accordance with the criteria. However, need for increasing on the component that is still lacking in order to better planning. SMK N 1 Cilegon can be reference in the preparation of the LIP. To improve the quality of teaching and graduates are in accordance with the needs of the AEC (Asean Economic Community).

\section{References}

Cooper, J.M., \& Tenbink, T.D. (2011). Classroom Teaching Skills, 10th Edition. Belmont: Wadsworth Cengage Learning.

Djamarah, S. B., \& Zain, A. (2006). Strategi belajar mengajar. Jakarta: Rineka Cipta.

Efendi, M. (2009). Kurikulum dan Pembelajaran: Pengantar ke Arah Pemahaman KBK, KTSP, dan SBI. Malang: Universitas Negeri Malang.

Hasan, H. (2013). Informasi kurikulum 2013. Bandung: Universitas Pendidikan Indonesia.

Majid, A. (2008). Perencanaan pembelajaran mengembangkan standar kompetensi guru. Bandung: PT. Remaja Rosdakarya.

Miarso, Y. (2008). Peningkatan kualifikasi guru dalam perspektif teknologi pendidikan. Jurnal Pendidikan Penabur, 10, 66-76.

Purwo, B. K. (2009). Menjadi guru pembelajar. Jurnal Pendidikan Penabur, 8(13), 64-70.

Ruhimat, T., et. al. (2011). Kurikulum dan pembelajaran. Jakarta: Rajawali Press.

Susilo, M. J. (2007). Kurikulum tingkat satuan pendidikan: manajemen pelaksanaan dan kesiapan sekolah menyongsongnya. Jakarta: Pustaka Pelajar.

Uno, H. B. (2007). Profesi kependidikan: problema, solusi, dan reformasi pendidikan di Indonesia. Jakarta: Bumi Aksara.

Zubaidah, S. (2010). Restrukturisasi Pemahaman Berbagai Istilah pada Penulisan Komponen Metode dalam Rencana Pelaksanaan Pembelajaran. Jurnal TEQIP. [on line] http://teqip.com/download/jteqip/jurnal-20-37.pdf 